\title{
PROCEDURA USTALANIA WŁAŚCIWEGO USTAWODAWSTWA W SPRAWIE O PODLEGANIE UBEZPIECZENIU SPOŁECZNEMU
}

\section{WPROWADZENIE}

Nie da się ukryć, że swoboda przepływu osób (pracowników) ${ }^{1}$ w ramach Unii Europejskiej (jako jedna z wartości TFUE), wynikające z niej ułatwienia w znoszeniu barier związanych z podejmowaniem pracy najemnej w innych krajach członkowskich, rosnąca mobilność osób fizycznych w obrębie tej wspólnoty, sprzyjają podejmowaniu pracy za granicą, także przez obywateli Rzeczypospolitej Polskiej. Fakt ten nie pozostaje obojętny z punktu widzenia praw i obowiązków związanych z zabezpieczeniem ryzyk socjalnych ${ }^{2}$. Dla przykładu różnice w składkach na ubezpieczenie społeczne w różnych państwach członkowskich sprawiają,

Dr hab. Grzegorz WolaK, prof. WSPiA Rzeszowskiej Szkoły Wyższej w Rzeszowie - Katedra Prawa Cywilnego i Prawa Pracy, ul. Cegielniana 14, 35-310 Rzeszów; e-mail: grzegorz.wolak@wspia. eu; https://orcid.org/0000-0003-3636-8440

${ }^{1}$ Trybunał Sprawiedliwości Unii Europejskiej uznaje, że ułatwienia wprowadzone przez traktat w dziedzinie swobody przemieszczania się nie mogą wywołać w pełni swych skutków, jeżeli obywatela państwa członkowskiego można zniechęcić do korzystania z nich wskutek ustanowionych przez ustawodawstwo państwa członkowskiego jego pochodzenia przeszkód dotyczących jego pobytu w przyjmującym państwie członkowskim, które powodują zaistnienie niekorzystnej dla niego sytuacji, jeżeli z tych ułatwień skorzysta. Uregulowanie krajowe, które stawia w gorszej sytuacji niektórych obywateli tego kraju z tego tylko powodu, że skorzystali oni ze swobody przemieszczania się i pobytu w innym państwie członkowskim, stanowi ograniczenie swobód gwarantowanych przez art. 18 WE każdemu obywatelowi Unii. Uregulowanie takie może być z punktu widzenia prawa wspólnotowego uzasadnione jedynie wtedy, gdy jest oparte na obiektywnych względach interesu ogólnego niezwiązanych z obywatelstwem osób, których dotyczy, i jest proporcjonalne do uzasadnionego celu, jaki realizuje prawo krajowe (zob. wyroki TSUE z: dnia 29 kwietnia $2004 \mathrm{r}$. w sprawie C-224/02 Pusa, Rec. s. I-5763, pkt 19; z dnia 26 października 2006 r. w sprawie C-192/05 Tas-Hagen i Tas, Zb. Orz. s. I-10451, pkt 30-31; z dnia 18 lipca 2006 r. w sprawie C-406/04 De Cuyper, Zb. Orz. s. I-6947, pkt 39-40).

${ }^{2}$ Zob. uzasadnienie postanowienia Sądu Najwyższego z dnia 18 lipca 2018 r., sygn. akt III UZ $10 / 18$, niepubl. 
że nierzadko dochodzić może do nadużyć w zakresie podlegania ubezpieczeniom społecznym ${ }^{3}$. Rodzi to problemy prawne, z jakimi muszą się zmierzyć polskie organy rentowe i sądy w sprawach o ustalenie podlegania ubezpieczeniom społecznym. Jednym $\mathrm{z}$ nich jest problem zbiegu tytułów do ubezpieczenia społecznego w ramach porządków prawnych dwóch państw członkowskich (sprawa z elementem transgranicznym), a więc wykraczający poza kwestie wynikające $\mathrm{z}$ ustawodawstwa krajowego (art. 9 ustawy z dnia 13 października 1998 r. o systemie ubezpieczeń społecznych ${ }^{4}$ ). Zagadnienia związane z migracją zarobkową zostały uregulowane w ustawodawstwie Unii Europejskiej. Koordynacja systemów zabezpieczenia społecznego państw członkowskich Unii opiera się w nim na zasadzie, że osoby przemieszczające się na terytorium Unii podlegają systemowi zabezpieczenia społecznego tylko jednego państwa członkowskiego. Podporządkowanie ustawodawstwu tylko jednego państwa członkowskiego oznacza stosowanie jego postanowień, tak jakby zainteresowany realizował swoją aktywność zawodową na terytorium jednego państwa ${ }^{5}$. Nie znaczy to, że jeśli idzie o materiał normatywny, wszystko jest jasne i klarowne. Jest raczej przeciwnie.

W artykule poruszona zostanie ogólnie problematyka procedury ustalania właściwego ustawodawstwa, uregulowanej w art. 16 rozporządzenia Parlamentu Europejskiego i Rady nr 987/2009 z dnia 16 września 2009 r. dotyczącego wykonywania rozporządzenia (WE) $\mathrm{nr} 883 / 2004 \mathrm{w}$ sprawie koordynacji systemów zabezpieczenia społecznego ${ }^{6}$. Rozważania skoncentrowane zostaną wokół kwestii ustalenia właściwego ustawodawstwa w przypadku jednoczesnego prowadzenia przez osobę fizyczną pozarolniczej działalności gospodarczej na terenie Polski oraz wykonywania pracy najemnej na terenie innego państwa członkowskiego np. Słowacji ${ }^{7}$. Kwestie te reguluje art. 13 ust. 3 rozporządzenia Parlamentu Europejskiego i Rady (WE) nr 883/2004 z dnia 29 kwietnia 2004 r. w sprawie koordynacji systemów zabezpieczenia społecznego ${ }^{8}$ oraz rozporządzenie wykonawcze. Prze-

${ }^{3}$ Zob. K. ŚlebZaK, Podleganie ubezpieczeniu społecznemu w przypadku jednoczesnego wykonywania pracy i prowadzenia działalności gospodarczej na terytorium przynajmniej dwóch państw członkowskich UE, „Praca i Zabezpieczenie Społeczne” 11 (2013), s. 34-35.

${ }^{4}$ Dz.U. z 2017 r., poz. 1778 z późn. zm.

${ }^{5}$ Zob. I. JęDRASIK-Jankowska, Pojęcia i konstrukcje prawne ubezpieczenia społecznego, Warszawa: LexisNexis 2012, s. 86.

${ }^{6}$ Dz. Urz. UE L 284.1 [dalej cyt.: rozporządzenie wykonawcze lub rozporządzenie Nr 987/2009].

${ }^{7}$ Zob. ŚLEBZAK, Podleganie, s. 30-35.

${ }^{8}$ Dz. Urz. UE L 2004.166.1 z późn. zm. [dalej cyt.: rozporządzenie podstawowe lub rozporządzenie $\mathrm{Nr}$ 883/2004]. Przepis art. 13 tego rozporządzenia dotyczy w zasadzie czterech grup problemów: 1) wykonywania pracy w przynajmniej dwóch państwach członkowskich (ust. 1);2) prowadzenia działalności w przynajmniej dwóch państwach członkowskich (ust. 2), 3) wykonywania pracy i prowadzenia działalności w przynajmniej dwóch państwach członkowskich (ust. 3), 4) pełnienia 
widuje on, że osoba, która normalnie wykonuje pracę najemną i pracę na własny rachunek w różnych państwach członkowskich, podlega ustawodawstwu państwa członkowskiego, w którym wykonuje pracę najemną. Jeśli zaś wykonuje ona pracę najemną $\mathrm{w}$ dwóch lub więcej państwach członkowskich podlega ustawodawstwu określonemu zgodnie z art. 13 ust. 1 rozporządzenia $\mathrm{Nr}$ 883/2004.

W sprawach dotyczących koordynacji systemów zabezpieczenia społecznego stosunek prawny, na podstawie którego powstaje tytuł ubezpieczenia społecznego i stosunek ubezpieczenia społecznego, to dwie niezależne więzi prawne, które mogą podlegać prawu różnych państw członkowskich, przy czym stosownie do generalnej reguły wspólnotowej koordynacji ubezpieczeń społecznych, stosunek ubezpieczenia społecznego podlega prawu miejsca wykonywania pracy (lex loci laboris). Temu prawu - stosownie do zasady koordynacji, która jest przeciwieństwem harmonizacji (ujednolicenia) systemów krajowych przez wprowadzenie unijnych pojęć lub instytucji - przyporządkowane jest zakwalifikowanie pracownika jako zatrudnionego $\mathrm{w}$ rozumieniu rozporządzenia podstawowego.

Bezpośrednim powodem napisania niniejszego artykułu było pytanie prawne zwykłego składu Sądu Najwyższego skierowane postanowieniem z dnia 18 lipca 2018r., sygn. akt III UZ 10/18, do składu powiększonego. W dalszej części artykułu kilkukrotnie odnosił się będę do argumentów przedstawionych przez Sąd Najwyższy w uzasadnieniu tego orzeczenia.

\section{STAN FAKTYCZNY SPRAWY III UZ 10/18}

Na potrzeby dalszych rozważań, także w celu skonkretyzowania omawianego problemu prawnego, zasadne będzie oparcie się na stanie faktycznym sprawy, w której zwrócono się z pytaniem prawnym do powiększonego składu Sądu Najwyższego. Przedstawiał się on następująco. D.Ś., prowadzący pozarolniczą działalność gospodarczą w Polsce (salon sukien ślubnych), zgłosił polskiemu organowi rentowemu fakt zawarcia umowy o pracę z A.B. - P.P.S. w innym państwie członkowskim UE, tj. na Słowacji. Uruchomiło to procedurę koncyliacyjną między organami ubezpieczenia społecznego zainteresowanych krajów (Polski i Słowacji), która doprowadziła do odmowy objęcia ubezpieczeniem społecznym z tytułu pracy najemnej (negatywna decyzja słowackiego organu rentowego - Sociálna poist'ovňa z dnia 22 sierpnia 2011 r.) oraz objęcia (kontynuacji ubezpieczenia społecznego) z racji prowadzonej w Polsce pozarolniczej działalności gospodarczej (pozytywna

służby urzędniczej i wykonywania pracy/prowadzenia działalności w przynajmniej dwóch państwach członkowskich (ust. 4). 
decyzja Zakładu Ubezpieczeń Społecznych Oddziału w J. z dnia 14 października 2015 r. ustalająca, że w okresie od 1 września 2010 r. do 28 lutego 2011 r. D.Ś. podlega ustawodawstwu polskiemu w zakresie zabezpieczenia społecznego). Ubezpieczony D.Ś. złożył odwołania od decyzji organów rentowych w kraju i za granicą. W odwołaniu do Sądu Okręgowego w K., podniósł, że decyzja o wyłączeniu go z ustawodawstwa słowackiego nie jest prawomocna. W piśmie z dnia 19 stycznia 2016 r. wywiódł, że Sąd Wojewódzki w Trnavie uchylił negatywną decyzję słowackiego organu rentowego. Mimo tego, Sąd Okręgowy w K. rozpoznał sprawę merytorycznie i oddalił jego odwołanie od decyzji Zakładu Ubezpieczeń Społecznych Oddziału w J. z dnia 14 października 2015 r.

Na skutek apelacji ubezpieczonego, Sąd Apelacyjny w R., uchylił wyrok sądu okręgowego i poprzedzającą go decyzję organu rentowego oraz przekazał sprawę do ponownego rozpoznania bezpośrednio organowi rentowemu. Stwierdził, że najpierw definitywnemu wyjaśnienia wymaga podleganie przez D.Ś. ubezpieczeniu społecznemu na Słowacji (musi dojść do zakończenia procedowania), a dopiero wówczas można rozstrzygać problem podlegania ubezpieczeniu społecznemu w Polsce. W przeciwnym wypadku decyzja Zakładu Ubezpieczeń Społecznych jak i wyrok Sądu Okręgowego w K. są przedwczesne. Nie zgodził się z tym z kolei organ rentowy, składając zażalenie do Sądu Najwyższego na kasatoryjny wyrok Sądu Apelacyjnego 9 .

\section{PROBLEMATYKA USTALANIA WŁAŚCIWEGO USTAWODAWSTWA (PROCEDURA KONCYLIACYJNA)}

Sąd Najwyższy w uzasadnieniu postanowienia z dnia 18 lipca 2018 r., sygn. akt III UZ 10/18, trafnie zwrócił uwagę na to, że problematyka ustalania właściwego ustawodawstwa ma zasadnicze znaczenie w związku z koniecznością zapewnienia podmiotom (obywatelom państw członkowskich UE) realnej ochrony ich praw z zakresu ubezpieczeń społecznych. Dodatkowo w art. 11 ust. 1 rozporządzenia $\mathrm{Nr}$ 883/2004 wyrażona została zasada podlegania ustawodawstwu tylko jednego państwa członkowskiego. $\mathrm{Z}$ tego względu rozporządzenie podstawowe i wykonawcze

\footnotetext{
${ }^{9}$ Postanowieniem z dnia 18 lipca 2018 r., sygn. akt III UZ 10/18, Sąd Najwyższy odroczył rozpoznanie sprawy i na podstawie art. $398^{17} \S 1$ k.p.c. przekazał do rozstrzygnięcia powiększonemu składowi Sądu Najwyższego następujące zagadnienie prawne: „Czy dochodzi do «nierozpoznania istoty sprawy» w rozumieniu art. $386 \S 4$ k.p.c. w związku z art. $477^{14 a}$ k.p.c. w sytuacji, gdy $\mathrm{w}$ sprawie o podleganie polskiemu ubezpieczeniu społecznemu w toku postępowania sądowego uchylona zostaje decyzja wydana przez organ rentowy innego państwa w przedmiocie niepodlegania ubezpieczeniu społecznemu w tym kraju?".
} 
pełnią rolę bufora, który zapobiega kumulacji tytułów ubezpieczenia społecznego, ale też strażnika (gwaranta), że wskutek działań poszczególnych państw członkowskich dany podmiot nie zostanie pozbawiony ochrony ubezpieczeniowej ${ }^{10}$. Istotny jest też w tym względzie czynnik temporalny. Chodzi o potrzebę szybkiego „załatwienia sprawy" przez ustalenie właściwego ustawodawstwa, przy czym skutek ostateczny jest poprzedzany ustawodawstwem tymczasowym ${ }^{11}$.

Pomimo wypływających z rozporządzenia podstawowego i wykonawczego postulatów szybkości postępowania oraz transparentności i efektywności ochrony, w praktyce może dojść do sytuacji nietypowej, w której odwołujący się nie ma tytułu do ubezpieczenia społecznego za granicą i nie ma tytułu ubezpieczenia społecznego w kraju, wobec uchylenia wyroku sądu pierwszej instancji oraz decyzji organu rentowego. Niezależnie od tego, jak długo taki niepożądany z punktu widzenia obu rozporządzeń okres potrwa, jest on bezpośrednio sprzeczny z celem art. 48-51 TWE (art. 39 i 42 w tekście skonsolidowanym), którym jest zapewnienie, aby pracownicy, w rezultacie wykorzystania prawa do swobodnego przepływu, nie tracili korzyści należnych im z zabezpieczenia społecznego na podstawie ustawodawstwa danego państwa członkowskiego ${ }^{12}$.

W rozporządzeniu podstawowym i wykonawczym zagadnienie ustalania ustawodawstwa właściwego zostało przewidziane w dwóch wypadkach. Po pierwsze - jednoczesnego wykonywania pracy bądź prowadzenia działalności na terytorium więcej aniżeli jednego państwa członkowskiego (art. 16 rozporządzenia wykonawczego), po drugie - pozostałych przypadkach ustalania ustawodawstwa właściwego (art. 6 rozporządzenia wykonawczego), w tym w szczególności w razie delegowania do wykonywania pracy na terytorium innego państwa członkowskiego bądź przejściowego prowadzenia działalności na terytorium innego państwa członkowskiego ${ }^{13}$.

Poinformowanie przez osobę wykonującą pracę bądź działalność gospodarczą bądź wreszcie wykonującą pracę i prowadzącą działalność gospodarczą w dwóch lub więcej państwach członkowskich instytucji wyznaczonej przez właściwą wła-

${ }^{10} \mathrm{Z}$ tego względu kwestia ważności stosunku pracy najemnej świadczonej w innym państwie członkowskim nie podlega ocenie polskiego organu rentowego, jak też sądu w postępowaniu odwoławczym (tak trafnie ŚlebzaK, Podleganie, s. 33).

${ }^{11}$ Zob. uzasadnienie postanowienia Sądu Najwyższego z dnia 18 lipca 2018 r., sygn. akt III UZ $10 / 18$.

12 Zob. wyroki TSUE z dnia 20 września 1994 r., C-12/93, A. Drake., ECR 1994, s. 4337; z dnia 26 maja 2005 r., C-249/04, J. Allard; z dnia 10 czerwca 1986 r., 60/85, M. E. S. Luijten, ECR 1986 , s. 2365; z dnia 3 maja 1990 r., C-2/89, K. von Heijningen; z dnia 16 lutego 1995 r., C-425/93, Calle Grenzshop Andresen GmbH \& Co. KG, ECR 1995, s. 269 (przytoczone przez Sąd Najwyższy w uzasadnieniu postanowienia w sprawie sygn. akt III UZ 10/18).

${ }^{13}$ Zob. K. ŚLEBZAK, Ustalenie ustawodawstwa tymczasowego na podstawie rozporzadzeń 883/2004 oraz 987/2009, „Praca i Zabezpieczenie Społeczne” 7 (2014), s. 2-7. 
dzę państwa członkowskiego, w którym ma miejsce zamieszkania, wymaga - ze względu na zaistnienie czynnika ponadkrajowego w ubezpieczeniu społecznym - zastosowania procedury przestrzegającej właściwości i kompetencji instytucji ubezpieczeń społecznych, przewidzianej w przepisach art. 16 rozporządzenia Parlamentu Europejskiego i Rady (WE) nr 987/2009. Informacja taka jest podstawą do niezwłocznego, lecz tylko wstępnego i tymczasowego ustalenia dla niej ustawodawstwa właściwego, stosownie do zasad kolizyjnych ustalonych w art. 13 rozporządzenia podstawowego. O tymczasowym określeniu prawa, według którego obejmuje się tę osobę ubezpieczeniem społecznym, instytucja miejsca zamieszkania wnioskodawcy informuje wyznaczone instytucje państwa, w którym wykonywana jest praca. Od tej chwili biegnie termin dwóch miesięcy, w czasie których przynajmniej jedna $\mathrm{z}$ zainteresowanych instytucji może poinformować instytucję miejsca zamieszkania o niemożności zaakceptowania ustalonego ustawodawstwa lub o swojej odmiennej opinii w tej kwestii. Gdy to nie nastąpi, tymczasowe określenie ustawodawstwa staje się ostateczne. Dopiero po zaakceptowaniu (również milczącym) przez zagraniczną instytucję ubezpieczeniową decyzji tymczasowej lub przeprowadzeniu wzajemnych uzgodnień w drodze procedury koncyliacji, możliwe jest wydanie decyzji ostatecznej. Na takim słusznym stanowisku stanął Sąd Najwyższy w wyroku z dnia 25 listopada 2016 r., sygn. akt I UK 370/15.

Jeżeli natomiast instytucja miejsca zamieszkania, na podstawie przedłożonych jej dokumentów, ma wątpliwości co do ustalenia właściwego ustawodawstwa, to zgodnie z art. 16 ust. 4 rozporządzenia $\mathrm{Nr}$ 987/2009, konieczne staje się nawiązanie kontaktów przez organy rentowe dwóch lub więcej państw członkowskich, a ustawodawstwo właściwe ustala się na mocy wspólnego porozumienia z uwzględnieniem art. 13 rozporządzenia $\mathrm{Nr}$ 883/2004 i art. 14 rozporządzenia $\mathrm{Nr}$ 987/2009. Krajowe systemy ubezpieczeń społecznych w Unii Europejskiej przewidują przy tym własne warunki objęcia tym ubezpieczeniem. Są to odrębne przepisy prawa materialnego, które samoistnie nie pozostają ze sobą w korelacji. Rozwiązania poszczególnych krajów jedynie koordynują (bez zastępowania rozwiązań prawnych państw członkowskich) przepisy prawa UE, to jest: rozporządzenie podstawowe ( $\mathrm{Nr} 883 / 2004)$ oraz rozporządzenie wykonawcze ( $\mathrm{Nr}$ 987/2009).

Niejednokrotnie dochodzić może do zderzenia porządków krajowych z prawem UE. Kolizja powstaje między innymi dlatego, że dodatkowa (choć z założenia nie musi być uboczna, marginalna) działalność osoby fizycznej spowoduje objęcie jej tym systemem ubezpieczenia społecznego, w którym ona nie ma woli dalszej partycypacji, mimo nawet zgodnych stanowisk organów rentowych poszczególnych zainteresowanych krajów co do stosowania wybranego sytemu ubezpieczenia społecznego. Problem wzmacnia fakt, że w polskim systemie prawnym podlega 
się ubezpieczeniu społecznemu z mocy prawa, a wolą stron nie można wyłączyć tego skutku ${ }^{14}$.

W sposób modelowy postępowanie koncyliacyjne normuje Decyzja Komisji Administracyjnej ds. Koordynacji Systemów Zabezpieczenia Społecznego nr A1 z dnia 12 czerwca 2009 r. w sprawie ustanowienia procedury dialogu i koncyliacji w zakresie ważności dokumentów, określenia ustawodawstwa właściwego oraz udzielania świadczeń na mocy rozporządzenia Parlamentu Europejskiego i Rady (WE) nr 883/2004 ${ }^{15}$. W punktach 5-11 przewiduje, że instytucja lub władza, która wyraża wątpliwość co do ważności dokumentu wydanego przez instytucję lub władzę innego państwa członkowskiego albo która nie zgadza się z (tymczasowym) określeniem ustawodawstwa właściwego, jest dalej zwana instytucją występującą. Instytucja innego państwa członkowskiego jest dalej zwana instytucją wezwaną. W przypadku wystąpienia wątpliwości instytucja występująca zwraca się do instytucji wezwanej o niezbędne wyjaśnienia dotyczące jej decyzji oraz, w stosownych przypadkach, o wycofanie lub orzeczenie nieważności danego dokumentu lub o dokonanie przeglądu lub unieważnienie jej decyzji. Instytucja występująca uzasadnia swój wniosek, wskazując na zastosowanie niniejszej decyzji, oraz dostarcza dowodów potwierdzających, stanowiących podstawę jej wniosku. Instytucja ta wskazuje osobę do kontaktu na okres pierwszego etapu procedury dialogu. Instytucja wezwana niezwłocznie potwierdza, poprzez email lub faks, otrzymanie wniosku, najpóźniej w terminie 10 dni roboczych od dnia jego otrzymania. Instytucja ta także wskazuje osobę do kontaktu na okres pierwszego etapu procedury dialogu. W możliwie najkrótszym czasie, najpóźniej w terminie trzech miesięcy od dnia otrzymania wniosku, instytucja wezwana informuje instytucję występującą o wyniku przeprowadzonego przez nią dochodzenia. Instytucja wezwana informuje instytucję występującą o potwierdzeniu pierwotnej decyzji, jej uchyleniu lub wycofaniu dokumentu albo stwierdzeniu jego nieważności. Instytucja ta zawiadamia także osobę zainteresowaną oraz, w stosownych przypadkach, jej pracodawcę, o swojej decyzji oraz o procedurach zaskarżenia tej decyzji, przewidzianych $w$ jej prawie krajowym. Jeżeli instytucja wezwana nie może zakończyć dochodzenia $\mathrm{w}$ terminie trzech miesięcy $\mathrm{z}$ uwagi na złożoność sprawy albo ze względu na fakt, że zweryfikowanie pewnych danych wymaga zaangażowania innej instytucji, może ona przedłużyć termin najdłużej o okres trzech miesięcy. Instytucja wezwana informuje instytucję występującą o przedłużeniu terminu w możliwie najkrótszym czasie, lecz co najmniej tydzień przed upłynięciem pierw-

\footnotetext{
${ }^{14}$ Zob. wyrok Sądu Najwyższego z dnia 13 września 2010 r., sygn. akt II UK 82/10, OSNAPiUS 2012, nr 1-2, poz. 21.

${ }^{15}$ Dz. U. UE C.2010.106.1 [dalej cyt.: Decyzja A1].
} 
szego terminu, uzasadniając opóźnienie oraz podając orientacyjny czas, w jakim dochodzenie zostanie zakończone.

Drugi etap procedury dialogu został określony w punktach 13-17 decyzji, z których wynika, że jeżeli instytucje nie mogą osiągnąć porozumienia w czasie pierwszego etapu procedury dialogu albo jeżeli instytucja wezwana nie może zakończyć dochodzenia w terminie 6 miesięcy od otrzymania wniosku, instytucje zawiadamiają właściwe władze. Każda z instytucji przygotowuje sprawozdanie ze swoich działań. Właściwe władze zainteresowanych państw członkowskich mogą zdecydować o rozpoczęciu drugiego etapu procedury dialogu albo o skierowaniu sprawy bezpośrednio do Komisji Administracyjnej. Jeżeli właściwe władze otworzą drugi etap procedury dialogu, każda z nich wyznacza główną osobę do kontaktu w terminie dwóch tygodni od zawiadomienia przez instytucję. Jeżeli podczas procedury dialogu osiągnięcie porozumienia nie jest możliwe, właściwe władze mogą skierować sprawę do Komisji Administracyjnej. Każda z właściwych władz przygotowuje dla Komisji Administracyjnej informację na temat głównych punktów spornych. Komisja Administracyjna stara się pogodzić rozbieżne opinie w terminie sześciu miesięcy od dnia, w którym skierowano do niej sprawę. Komisja może zdecydować o skierowaniu sprawy do Komisji Pojednawczej, która może zostać powołana na podstawie regulaminu Komisji Administracyjnej.

\section{ZAPATRYWANIA SĄDU NAJWYŻSZEGO}

Jeśli idzie o sytuację, w której w tym samym czasie (równocześnie) prowadzona jest przez określoną osobę działalność gospodarcza w kraju i praca najemna za granicą, to była ona już przedmiotem wypowiedzi Sądu Najwyższego. Warto zaprezentować poniżej judykaty traktujące o tej kwestii. Wywody w nich zawarte nie wyczerpują oczywiście tej złożonej problematyki.

1. W wyroku Sądu Najwyższego z dnia 6 czerwca 2013 r., sygn. akt II UK $333 / 12^{16}$, przyjęto, iż z art. 1 pkt a rozporządzenia podstawowego wynika, że do celów stosowania rozporządzenia określenie „praca najemna” oznacza wszelką pracę lub sytuację równoważną, traktowaną jako taką do celów stosowania ustawodawstwa w zakresie zabezpieczenia społecznego państwa członkowskiego, w którym taka praca lub sytuacja równoważna ma miejsce. Istotne jest zatem, że określona osoba weszła w stosunki ubezpieczenia społecznego o charakterze transgranicznym przez jednoczesne wykonywanie działalności w różnych państwach i konieczne było zbadanie, czy spełnia warunki ubezpieczenia ustanowione przez

\footnotetext{
${ }^{16}$ OSNAPiUS 2014, nr 3, poz. 47.
} 
system zabezpieczenia społecznego w prawie krajowym wskazanym przez normy kolizyjne jako właściwe ${ }^{17}$. W tym wypadku organ ubezpieczeń społecznych miejsca zamieszkania takiej osoby był uprawniony do wskazania ustawodawstwa właściwego stosownie do art. 13 ust. 3 rozporządzenia podstawowego ${ }^{18}$. Zdaniem Sądu Najwyższego nie miał on natomiast kompetencji do oceny zaistnienia stosunku ubezpieczenia w sensie prawnym. Ocena ta mogła nastąpić wyłącznie na podstawie wskazanych przez normę kolizyjną przepisów miejsca świadczenia pracy i być dokonana tylko przez organ władny te przepisy stosować. Ze względu na różnice między ustawodawstwami krajowymi co do określenia przedmiotu ubezpieczenia społecznego wprowadzono zasadę, że uwzględnianie okoliczności lub wydarzeń mających miejsce w jednym państwie członkowskim nie może w żaden sposób sprawiać, iż właściwe dla nich stanie się inne państwo ani że będzie się do nich stosować jego ustawodawstwo (pkt 11 preambuły rozporządzenia podstawowego). Określenie ustawodawstwa właściwego wskazującego na instytucję miejsca świadczenia pracy najemnej wyłącza ocenę przez instytucję miejsca zamieszkania, czy stosunek prawny będący podstawą objęcia ubezpieczeniem społecznym w kraju świadczenia pracy jest ważny według prawa miejsca zamieszkania ubezpieczonego. Sąd Najwyższy odwołał się w tym zakresie do wyroku Sądu Najwyższego z dnia 23 sierpnia 2007 r., sygn. akr sygn. akt I UK 68/07, w którym uznano, że nie jest dopuszczalna ocena stosunku prawnego stanowiącego tytuł ubezpieczenia społecznego w innym państwie członkowskim przez instytucję miejsca zamieszkania osoby wnoszącej o ustalenie właściwego ustawodawstwa. Stwierdzenia spełnienia warunków ubezpieczenia społecznego w systemie prawnym państwa wykonywania pracy podlegającym koordynacji na podstawie rozporządzenia nr 883/04 dokonują organy właściwe do stosowania tego prawa ${ }^{19}$. Nie może budzić wątpliwości, że instytucja miejsca zamieszkania osoby ubiegającej się o ustalenie ubezpieczenia społecznego w innym państwie może powziąć wątpliwości co do określenia mającego zastosowanie ustawodawstwa, lecz trzeba podkreślić, iż może chodzić jedynie o wątpliwości co do określenia ustawodawstwa mającego zastosowanie do zainteresowanego, z uwzględnieniem art. 13 rozporządzenia

\footnotetext{
${ }^{17}$ Zob. wyrok Europejskiego Trybunału Sprawiedliwości z dnia 15 grudnia 1976 r., C-39/76, L.J. Mouthaan, OCR 1976, s. 1901; wyrok Trybunału Sprawiedliwości Unii Europejskiej z dnia 10 marca 2011 r., C-516/09, T. Borger, C 139/8 Dz. Urz. UE 2011/C 139, poz. 11.

${ }^{18}$ Zob. też wyrok Sądu Najwyższego z dnia 23 sierpnia 2007 r., sygn. akt I UK 68/07, OSNAPiUS 2008, nr 19-20, poz. 300.

${ }^{19} \mathrm{~W}$ piśmiennictwie K. Ślebzak również jest zdania, że w sprawach o ustalenie ustawodawstwa właściwego na podstawie przepisów wspólnotowej koordynacji nie jest dopuszczalna ocena przez instytucję miejsca zamieszkania stosunku prawnego stanowiącego tytuł do ubezpieczenia społecznego (np. stosunku pracy) w innym państwie członkowskim (zob. ŚLEBZAK, Podleganie, s. 34).
} 
podstawowego i odpowiednich przepisów art. 14 rozporządzenia wykonawczego, czyli niepewności co do tego, czy osoba wnosząca o ustalenie prawa właściwego jest objęta systemem zabezpieczenia społecznego w więcej niż jednym państwie członkowskim. Wątpliwości tych instytucja miejsca zamieszkania skarżącego nie może sama rozstrzygać, lecz musi dostosować się do trybu rozwiązywania sporów co do ustalenia ustawodawstwa właściwego wskazanego w szczególności w art. 6, 15 oraz 16 rozporządzenia wykonawczego, które nakazują zwrócenie się - w przypadku istnienia wątpliwości bądź rozbieżności - do instytucji innego państwa członkowskiego. Instytucje niezwłocznie dostarczają lub wymieniają między sobą wszystkie dane niezbędne dla ustanowienia i określenia praw i obowiązków osób, do których ma zastosowanie rozporządzenie podstawowe.

2. W wyroku z dnia 25 listopada 2016 r., sygn. akt I UK 370/15²0, Sąd Najwyższy stwierdził, że zgodnie z art. 13 ust. 3 rozporządzenia nr 883/2004, osoba, która normalnie wykonuje pracę najemną i pracę na własny rachunek w różnych państwach członkowskich podlega ustawodawstwu państwa członkowskiego, w którym wykonuje swą pracę najemną. W celu zastosowania tej zasady regulacje unijne określają procedurę postępowania wyznaczonych instytucji ubezpieczeniowych zainteresowanych państw członkowskich. Procedurę tę określa art. 16 rozporządzenia nr 987/2009. Dla ustalenia kompetencji organu rentowego oraz sądów polskich $\mathrm{w}$ zakresie ustalenia istnienia zatrudnienia pracowniczego $\mathrm{w}$ innym państwie członkowskim, istotne znaczenie ma stanowisko przyjęte w wyroku Sądu Najwyższego z 6 czerwca 2013 r., sygn. akt II UK 333/12. Wynika z niego, że do organu rentowego, jak również do sądu polskiego, należy przede wszystkim ustalenie, czy osoba uprawniona podlega ubezpieczeniu społecznemu w danym państwie członkowskim, a nie ustalenie, czy ważny jest stosunek prawny będący podstawą objęcia jej ubezpieczeniem społecznym w tym państwie. Jeżeli organ rentowy poweźmie wątpliwości co do ważności stosunku prawnego będącego podstawą objęcia tytułem ubezpieczenia społecznego w innym państwie członkowskim w ramach postępowania w przedmiocie ustalenia ustawodawstwa właściwego, to nie może samodzielnie przesądzać tej kwestii. Przedstawione zasady ulegają pewnym modyfikacjom w sytuacji, gdy wykonywana praca miała charakter marginalny lub wnioskodawca w ogólne nie wykonywał żadnych czynności na terenie drugiego państwa. Z dniem 28 czerwca 2012 r. do art. 14 rozporządzenia nr 987/2009 dodano ust. 5b („Praca o charakterze marginalnym nie będzie brana pod uwagę do celów określenia mającego zastosowanie ustawodawstwa na mocy art. 13 rozporządzenia podstawowego. Art. 16 rozporządzenia wykonawczego stosuje się we wszystkich przypadkach objętych niniejszym artykułem"). Wykonywanie

\footnotetext{
${ }^{20}$ LEX nr 2166375.
} 
pracy za granicą $\mathrm{w}$ rozmiarze kilku godzin w okresie miesiąca (po odliczeniu czasu dojazdu) zostało ocenione w judykaturze jako niewątpliwie stanowiące pracę o charakterze marginalnym ${ }^{21}$. Sąd Najwyższy uznał, że przepis art. 14 ust. 5b rozporządzenia nr 987/2009 miał zastosowanie do oceny skargi kasacyjnej. Po otrzymaniu wniosku polski organ prowadził postępowanie w aspekcie, czy wskazana w nim umowa o pracę najemną miała charakter marginalny. Z przepisu tego wynika jednoznacznie, że wydanie w sprawach koordynacji decyzji tymczasowej nie musi uwzględniać wniosku pracownika. Korzystne rozstrzygnięcie dla pracownika następuje tylko wtedy, gdy jego praca nie cechowała się charakterem marginalnym. Ostateczną decyzję wydaje instytucja ubezpieczenia społecznego kraju, w którym złożono wniosek o ustalenie właściwego ustawodawstwa, ale w takiej sprawie powinno najpierw dojść do ustalenia właściwego ustawodawstwa w drodze decyzji tymczasowej, doręczonej właściwemu organowi zagranicznemu na podstawie art. 16 ust. 1 rozporządzenia Parlamentu Europejskiego i Rady (WE) nr 987/2009. Dopiero po zaakceptowaniu (również milczącym) przez zagraniczną instytucję ubezpieczeniową decyzji tymczasowej lub przeprowadzeniu wzajemnych uzgodnień w drodze procedury koncyliacji, możliwe jest wydanie decyzji ostatecznej. Sąd, w postępowaniu odwoławczym od takiej decyzji, skupia uwagę na zachowaniu właściwej procedury wydania decyzji, gdyż jego kompetencje do oceny stanu prawnego w innym państwie unijnym podlegają ograniczeniom, wynikającym również z konieczności sprawnego i szybkiego załatwiania takich spraw. Stwierdzenia spełnienia warunków ubezpieczenia społecznego oraz marginalnego charakteru pracy najemnej w systemie prawnym państwa wykonywania pracy, podlegającym koordynacji na podstawie rozporządzenia $\mathrm{nr} 883 / 04$, dokonują organy właściwe do stosowania tego prawa. W ocenie Sądu Najwyższego nie może budzić wątpliwości, że instytucja miejsca zamieszkania osoby ubiegającej się o ustalenie ubezpieczenia społecznego w innym państwie może powziąć wątpliwości co do określenia mającego zastosowanie ustawodawstwa z uwagi na marginalny charakter takiej pracy w jednym z państw unijnych. Może jednak chodzić jedynie o wątpliwości co do określenia ustawodawstwa mającego zastosowanie do wnioskodawcy, z uwzględnieniem art. 13 rozporządzenia nr 883/04 i odpowiednich przepisów art. 14 rozporządzenia nr 987/2009. Wątpliwości tych instytucja miejsca zamieszkania wnioskodawcy nie może sama rozstrzygać, lecz musi dostosować się do trybu rozwiązywania sporów co do ustalenia ustawodawstwa właściwego, wskazanego w szczególności w art. 6, 15 oraz 16 rozporządzenia nr 987/2009, które nakazują zwrócenie się - w przypadku istnienia wątpliwości bądź rozbieżności - do in-

${ }^{21}$ Zob. wyrok Sądu Najwyższego z dnia 21 stycznia 2016 r., sygn. akt III UK 61/15, LEX nr 1977828. 
stytucji innego państwa członkowskiego. Instytucje niezwłocznie dostarczają lub wymieniają między sobą wszystkie dane niezbędne dla ustanowienia i określenia praw i obowiązków osób, do których ma zastosowanie rozporządzenie podstawowe. Przekazywanie tych danych odbywa się bezpośrednio pomiędzy samymi instytucjami lub za pośrednictwem instytucji łącznikowych. Zastosowanie znajduje również decyzja $\mathrm{Nr}$ A1.

3. W wyroku z dnia 21 stycznia 2016 r., sygn. akt III UK 61/1522, Sąd Najwyższy mając na uwadze pkt 12 preambuły do rozporządzenia nr 883/2004 oraz dążąc do tego, aby „w świetle zasady proporcjonalności zadbać o to, by zasada uwzględniania okoliczności lub wydarzeń nie prowadziła do obiektywnie nieuzasadnionych rezultatów ani do kumulacji świadczeń tego samego rodzaju za ten sam okres" uznał, że w przypadku uzasadnionych podejrzeń dotyczących zgodności z prawdą przedłożonych umów o pracę, Zakład Ubezpieczeń Społecznych jest uprawniony do żądania niezwłocznego nadesłania przez wnioskodawcę dokumentów dotyczących rzeczywistego pobytu i pracy w innym kraju. Osoba, która rzeczywiście taką pracę wykonuje nie będzie miała żadnych problemów z nadesłaniem na przykład kopii umowy najmu mieszkania za granicą, albo biletów autokarowych lub lotniczych, choćby z ostatniego miesiąca. Wówczas polski organ ubezpieczeniowy powinien w ciągu kilku dni wydać pozytywną dla wnioskodawcy decyzję tymczasową w kwestii właściwego ustawodawstwa. W przypadku jednak niedających się usunąć wątpliwości, uzasadnionych również wcześniejszymi informacjami dotyczącymi pracodawcy, konieczne jest zwrócenie się do instytucji ubezpieczeniowej innego państwa w przedstawionym wyżej trybie i wydanie decyzji tymczasowej.

4. Z kolei w wyroku Sądu Najwyższego z dnia 10 maja 2017 r., sygn. akt I UK $456 / 16^{23}$ przyjęto, że przepis art. 2 ust. 2 rozporządzenia $\mathrm{Nr}$ 883/2004 nie stanowi podstawy prawnej do stwierdzenia, czy praca wykonywana przez określoną osobę miała lub nie miała charakteru marginalnego. Polski organ rentowy (jako instytucja właściwa według miejsca zamieszkania wnioskodawcy) nie ma kompetencji do oceny spełnienia warunków objęcia wnioskodawcy ubezpieczeniem społecznym w innym państwie członkowskim z tytułu wykonywania tam pracy najemnej. Wykładnia art. 13 ust. 3 rozporządzenia nr 883/2004 jest w sposób konieczny i systemowy powiązana z wykładnią art. 14 ust. 5b rozporządzenia Parlamentu Europejskiego i Rady (WE) nr 987/2009 w ten sposób, że dla ustalenia ustawodawstwa właściwego w zakresie zabezpieczenia społecznego zrekonstruowana w ten sposób norma ma następującą treść: „Osoba, która normalnie wykonuje pracę najemną i pracę na własny rachunek w różnych Państwach Członkowskich

\footnotetext{
22 Tamże.

${ }^{23}$ LEX nr 2352167.
} 
podlega ustawodawstwu Państwa Członkowskiego, w którym wykonuje swą pracę najemną, chyba że wykonywana praca ma charakter marginalny". Należy zatem przyjąć, że dokonywana przez właściwe instytucje ocena charakteru pracy najemnej jako marginalnej w rozumieniu art. 14 ust. 5b rozporządzenia wykonawczego w niczym nie uchybia regule kolizyjnej wyrażonej w art. 13 ust. 3 rozporządzenia podstawowego. Sąd Najwyższy wskazał, że legitymowanie się poświadczeniem na formularzu Al o podleganiu ubezpieczeniu społecznemu w państwie członkowskim miejsca wykonywania pracy najemnej nie może być ignorowane przy ustaleniu ustawodawstwa mającego zastosowanie do zainteresowanego $\mathrm{w}$ trybie art. 16 rozporządzenia wykonawczego i dopiero jego wycofanie lub uznanie za nieważne, po ponownym rozpatrzeniu podstaw jego wydania, umożliwia ustalenie ustawodawstwa państwa członkowskiego miejsca zamieszkania. Natomiast jeśli chodzi o dokument $\mathrm{w}$ postaci poświadczenia rejestracji w systemie ubezpieczenia społecznego innego państwa członkowskiego, to jest on tylko dowodem zgłoszenia do ubezpieczenia, które samo w sobie nie przesądza o istnieniu ważnego tytułu do objęcia ubezpieczeniem (postanowienie Sądu Najwyższego z dnia 20 października 2016 r., sygn. akt I UZ 22/16). Jeżeli organ rentowy poweźmie wątpliwości co do ważności stosunku prawnego będącego podstawą objęcia tytułem ubezpieczenia społecznego w innym państwie członkowskim $\mathrm{w}$ ramach postępowania $\mathrm{w}$ przedmiocie ustalenia ustawodawstwa właściwego, to nie może samodzielnie przesądzać tej kwestii ${ }^{24}$.

\section{PROBLEM RELACJI HORYZONTALNEJ POSTĘPOWAŃ KRAJOWYCH WZGLĘDEM SIEBIE}

Konsekwencją braku akceptacji wyników procedury koncyliacyjnej jest uprawnienie do poddania kontroli sądowej werdyktu zarówno pozytywnego (decyzja polskiego organu ubezpieczenia społecznego o objęciu ubezpieczeniem społecznym z racji prowadzonej działalności gospodarczej w kraju) jak i negatywnego (odmowa objęcia ubezpieczeniem społecznym w innym państwie członkowskim, np. na Słowacji, z racji świadczenia pracy dobrowolnie podporządkowanej w ramach stosunku pracy). Oba postępowania toczą się już według prawa krajowego (odnośnie do prawa materialnego i procesowego), mając jednak na horyzoncie rozwiązania rozporządzenia podstawowego i wykonawczego. Rodzi to problem relacji horyzontalnej postępowań krajowych względem siebie ${ }^{25}$.

\footnotetext{
${ }^{24}$ Zob. też ŚlebZaK, Podleganie, s. 33.

${ }^{25}$ Tak trafnie Sąd Najwyższy w uzasadnieniu postanowienia w sprawie sygn. akt III UZ 10/18.
} 
Na gruncie polskiego systemu prawnego problematyka wzajemnych zależności postępowań sądowych uregulowana jest w przepisach Kodeksu postępowania cywilnego. Jak zauważył Sąd Najwyższy w uzasadnieniu postanowienia z dnia 18 lipca 2018r., sygn. akt III UZ 10/18, automatycznie nasuwa się wniosek o konieczności zawieszenia postępowania, skoro toczy się inny spór. Jednak w świetle art. 174 k.p.c. inne toczące się postępowanie sądowe nie stanowi podstawy do obligatoryjnego zawieszenia postępowania cywilnego. Zgodnie natomiast $\mathrm{z}$ art. 177 $\S 1$ pkt 1 k.p.c. jeżeli rozstrzygnięcie sprawy zależy od wyniku innego toczącego się postępowania cywilnego, sąd jedynie może zawiesić sprawę. W przepisie tym chodzi jednak o inne postępowanie cywilne toczące się przed sądem polskim. Fakultatywne jest zawieszenie postępowania, nawet gdy spór toczy się przed Trybunałem Konstytucyjnym czy też przed Trybunałem Sprawiedliwości Unii Europejskiej (art. $177 \S 1$ pkt $3^{1}$ k.p.c.).

Ocenę tę, jak się wydaje, modyfikuje odwołanie się do dyspozycji art. 1098 k.p.c. (część czwarta - przepisy z zakresu międzynarodowego postępowania cywilnego, księga pierwsza - jurysdykcja krajowa). W myśl art. 1098 § 1 k.p.c. jeżeli sprawa o to samo roszczenie między tymi samymi stronami zawisła przed sądem państwa obcego wcześniej niż przed sądem polskim, sąd polski zawiesza postępowanie. Sąd nie zawiesza jednak postępowania, jeżeli orzeczenie, które ma wydać sąd państwa obcego, nie będzie spełniało przesłanek jego uznania w Rzeczypospolitej Polskiej lub nie można oczekiwać, że postępowanie przed sądem państwa obcego zostanie prawomocnie zakończone w rozsądnym terminie. Konkurencja między postępowaniem zagranicznym a postępowaniem toczącym się przed sądem polskim ma być rozstrzygnięta według zasady pierwszeństwa czasowego. Obowiązek zawieszenia postępowania przed sądem polskim istnieje tylko wtedy, gdy sprawa przed sądem zagranicznym zawisła wcześniej niż przed sądem polskim (uprzednia zawisłość w stosunku do zawisłości sprawy przed sądem krajowym) ${ }^{26}$.

W tym zakresie problematyczna może wydawać się jednak kwestia tożsamości roszczenia. O ile bowiem w obu sprawach (w Polsce i na Słowacji) odwołującym się jest ten sam podmiot (D.Ś.), o tyle po stronie pozwanej nie ma już tożsamości stron (są nimi: polski i słowacki organ rentowy). Gramatycznie roszczenia są także odmienne, gdyż chodzi o objęcie innym systemem prawa ubezpieczeń społecznych. Także wywodzone $\mathrm{z}$ nich podstawy faktyczne (tytuły objęcia ubezpieczeniem społecznym) są różne. Nie należy jednak tracić z pola widzenia tego, że o tożsamości roszczenia można mówić wówczas, gdy poszukiwany za ich pomocą cel

${ }^{26}$ T. EREciŃsKi, Komentarz do art. 1098, [w:] Kodeks postępowania cywilnego. Komentarz. Tom VI. Międzynarodowe postępowanie cywilne. Sąd polubowny (arbitrażowy), red. T. Ereciński, Warszawa: Wolters Kluwer 2017, Lex/el., pkt 7. 
ochrony prawnej jest ten sam. Ujmując to inaczej, tożsamość roszczeń ma miejsce nie tylko w razie nominalnej zgodności żądania i jego uzasadnienia, lecz także wtedy, gdy mimo pewnych odmienności w powyższym zakresie mają one ten sam cel $^{27}$. W doktrynie prawa europejskiego wypracowano też tzw. teorię ,,punktów istotnych", która zakłada tożsamość roszczeń ze względu na ich wspólny rdzeń wyznaczany przez częściową tożsamość żądań i ich podstaw faktycznych, tożsamy cel oraz ukierunkowanie na zaspokojenie tożsamych interesów ${ }^{28}$.

Również art. $1098^{1}$ k.p.c. stanowi, że jeżeli rozstrzygnięcie sprawy zależy od wyniku innego postępowania w sprawie cywilnej toczącego się przed sądem lub innym organem państwa obcego, sąd może zawiesić postępowanie z urzędu, chyba że orzeczenie, które ma wydać sąd albo inny organ państwa obcego, nie spełni przesłanek jego uznania w Rzeczypospolitej Polskiej. Także rozporządzenie Parlamentu Europejskiego i Rady (UE) nr 1215/2012 z dnia 12 grudnia 2012 r. w sprawie jurysdykcji i uznawania orzeczeń sądowych oraz ich wykonywania w sprawach cywilnych i handlowych ${ }^{29}$, przewiduje możliwość zawieszenia postępowania cywilnego przez sąd, w którym proces rozpoczął się później (art. 30).

W sprawach z odwołań D.Ś. od strony funkcjonalnej cel jest wspólny. Uruchomienie drogi sądowej zmierza de facto do uzyskania ochrony z zakresu ubezpieczeń społecznych w systemie prawa słowackiego. Akceptując argument o tożsamości roszczenia w ujęciu ponadkrajowym (jest nim poszukiwanie ochrony przed sądem w ramach realizacji prawa do swobodnego przemieszczania się w obrębie UE), możliwe jest uzyskanie efektu w postaci zawieszenia postępowania przed polskim sądem, zwłaszcza że postępowanie w innym kraju UE dotyczy decyzji organu rentowego, która została wydana wcześniej. Dlatego należy postulować, aby do czasu zakończenia postępowania w innym państwie członkowskim UE, gdzie toczy się wcześniej wszczęte postępowanie o ustalenie podleganiu ubezpieczeniom społecznym z tytułu pracy najemnej świadczonej w tym państwie, organy polskie zawieszały swoje postępowanie wszczęte później. Nawet gdyby nie podzielić stanowiska o tożsamości roszczenia, to i tak podstawa, tyle że fakultatywna, do zawieszenia postępowania znajduje się w art. $1098^{1}$ k.p.c.

${ }^{27}$ Zob. J. Mucha, Zawistość sprawy w procesie cywilnym, Warszawa: Wolters Kluwer 2014, s. 293-294; A. Torbus, Komentarz do art. 1098, [w:] Kodeks postepowania cywilnego. Tom IV. Komentarz. Art. 1096-1217, red. A. Marciniak, Warszawa: C.H. Beck 2017,, Legalis/el., nb. 32; postanowienie Sądu Najwyższego z dnia 1 czerwca 2011 r., sygn. akt II CSK 427/10, Legalis; uzasadnienie postanowienia Sądu Najwyższego z dnia 10 lipca 2018 r., sygn. akt III UZ 10/18.

${ }^{28}$ Zob. wyrok Trybunału Sprawiedliwości Unii Europejskiej z dnia 14 października 2004 r. w sprawie C-39/02, Marsk Olie \& Gas A/S v. Firma M. de Haan en W. de Boer.

${ }^{29}$ Dz. Urz. UE L 351 z późn. zm. 
Wątpliwości co do wyboru systemu ubezpieczenia instytucja rentowa miejsca zamieszkania wnioskodawcy nie może rozstrzygać sama, lecz musi dostosować się do trybu rozwiązywania sporów co do ustalenia ustawodawstwa właściwego wskazanego w szczególności w art. 6, art. 15 oraz art. 16 rozporządzenia wykonawczego. Chodzi o wymianę między organami rentowymi wszystkich danych, które są potrzebne dla ustanowienia i określenia praw i obowiązków osób, do których ma zastosowanie rozporządzenie podstawowe. Zastosowanie ma również decyzja $\mathrm{Nr}$ Al. Wystąpienie więc czynnika ponadkrajowego w ubezpieczeniu społecznym uruchamia specjalny tryb. Może on pierwotnie doprowadzić do wstępnego i tymczasowego ustalenia ustawodawstwa właściwego, stosownie do zasad kolizyjnych ustalonych w art. 13 rozporządzenia podstawowego. To ustawodawstwo stanie się ostateczne, po upływie dwóch miesięcy, jeżeli jedna z zainteresowanych instytucji nie zgłosi zastrzeżeń co do ustalonego ustawodawstwa lub swojej odmiennej opinii w tej kwestii.

Nieuruchomienie tego specjalnego trybu w przypadku wystąpienia w sprawie czynnika ponadkrajowego w ubezpieczeniu społecznym jest istotnym naruszeniem przepisów postępowania cywilnego. Wydaje się, że naruszenie to nosi znamiona „nierozpoznania istoty sprawy”. Prawo unijne oddziałuje na prawo krajowe także w taki sposób, że w sprawach unijnych może wymagać nadania utrwalonym instytucjom prawa krajowego innego znaczenia, niż dotychczas przyjęte, a nawet innego znaczenia w różnych stanach faktycznych ${ }^{30}$. W konsekwencji uprawnione wydaje się przyjęcie, że kasatoryjne rozstrzygnięcie sądu drugiej instancji, o którym mowa $\mathrm{w}$ art. $386 \S 4$ k.p.c. (w razie nierozpoznania przez sąd pierwszej instancji istoty sprawy), przy uwzględnieniu prounijnej wykładni prawa, jest możliwe także wtedy, gdy ustalone w toku procedury koncyliacyjnej ustawodawstwo jednego kraju członkowskiego odnośnie do wyboru określonego systemu ubezpieczenia społecznego, zostało zanegowane przed sądem państwa miejsca wykonywania pracy (lex loci laboris), niwecząc ze skutkiem erga omnes dotychczasowe ustalenia krajowych organów rentowych ${ }^{31}$. W takiej sytuacji ani polski organ rentowy, ani sąd nie mogą rozstrzygnąc merytorycznie sprawy o podleganie ubezpieczeniu społecznemu dopóki decyzja składająca się na wspólne porozumienie organów dwóch państw członkowskich nie stanie się ostateczna.

Należy zgodzić się z Sądem Najwyższym, który w uzasadnieniu postanowienia w sprawie sygn. akt III UZ 10/18, stwierdza, że sąd nie jest arbitrem rozstrzyga-

${ }^{30}$ Zob. uzasadnienie postanowienia Sądu Najwyższego z dnia 10 lipca 2018 r., sygn. akt III UZ 10/18.

${ }^{31} \mathrm{~W}$ tym kierunku szły rozważania Sądu Najwyższego zawarte w uzasadnieniu postanowienia z dnia 10 lipca 2018 r., sygn. akt III UZ 10/18. 
jącym, jakie ustawodawstwo będzie miało zastosowanie. Wynika to w sposób jednoznaczny $\mathrm{z}$ art. 6 ust. $3 \mathrm{w}$ związku z art. 16 ust. 4 in fine rozporządzenia wykonawczego, zgodnie $\mathrm{z}$ którym, w przypadku gdy zainteresowane instytucje lub władze nie osiągną porozumienia co do określenia mającego zastosowanie ustawodawstwa, sprawa może zostać przedstawiona Komisji Administracyjnej przez właściwe władze, a Komisja Administracyjna stara się pogodzić rozbieżne opinie w terminie sześciu miesięcy od dnia, w którym przedstawiono jej sprawę. Żaden z przepisów rozporządzenia wykonawczego nie obliguje państwa miejsca zamieszkania do wdania się w spór z państwem miejsca świadczenia pracy najemnej. Taki spór oczywiście może mieć miejsce w praktyce i będzie wymagał rozstrzygnięcia w trybie przewidzianym w rozporządzeniu wykonawczym. Dotychczas Sąd Najwyższy przy wstępnym badaniu skarg kasacyjnych, w ramach przedsądu, nie uznawał informacji o podstawach do ubezpieczenia społecznego za granicą za uzasadnienie do przyjęcia tych skarg do rozpoznania i to nawet wówczas, gdy skarżący podnosili fakt niezakończenia postępowania przed słowackim organem rentowym, domagając się jednocześnie zawieszenia postępowania w kraju do czasu jego zakończenia ${ }^{32}$. Taką praktykę, w mojej ocenie uznać należy za wadliwą.

Prawidłowa jest też teza Sądu Najwyższego (sygn. akt III UZ 10/18) o istnieniu mocnych argumentów za zbudowaniem wnioskowania opartego na regule dynamicznej zależności horyzontalnej postępowań sądowych z uwagi na to, że jedno toczące się postępowanie sądowe przed sądem krajowym jest horyzontalnie zależne od innego postępowania przed sądem krajowym innego państwa członkowskiego. Nie może zatem się skończyć bez uwzględnienia jego wyniku (tu wyniku postępowania przed sądem słowackim). Łącznikiem obu tych postępowań może być konieczność zapewnienia pełnej skuteczności norm prawa Unii Europejskiej, które korzystają z zasady pierwszeństwa i bezpośredniego skutku przed prawem krajowym ${ }^{33}$. Jak trafnie dalej wywiódł Sąd Najwyższy w uzasadnieniu tego postanowienia, w sprawie o podleganie ubezpieczeniu społecznemu na organie rentowym i sądzie, w ramach rozpoznania odwołania, ciąży obowiązek szerszego osądu sprawy, to jest nie tylko z perspektywy prawa krajowego, lecz także prawa Unii Europejskiej. Mamy tu do czynienia ze sprawą unijną, czyli taką, w której zachodzi konieczność (obowiązek) uwzględnienia prawa unijnego i jego zasad przy formułowaniu podstawy prawnej rozstrzygnięcia oraz jego treści. Przedmiotowy

${ }^{32}$ Zob. postanowienia Sądu Najwyższego: z dnia 14 listopada 2017 r., sygn. akt II UK 692/16, niepubl. i z dnia 10 kwietnia 2018 r., sygn. akt II UK 271/17, LEX nr 2510216.

${ }^{33}$ Zob. D. MiąsiK, Zasada pierwszeństwa prawa wspólnotowego przed prawem krajowym wprowadzenie i wyrok Trybunału Sprawiedliwości Wspólnot Europejskich z 29.04.1999 r. w sprawie C-224/97 Erich Ciola przeciwko Land Voralberg, „Europejski Przegląd Sądowy” 1 (2006), s. 54-56. 
obowiązek wyraża się konglomeratem temporalnych, podmiotowych i przedmiotowych faktorów wchodzących w obręb prawa unijnego ${ }^{34}$.

W tym kontekście nie można też zapomnieć o charakterze decyzji organu rentowego. Decyzja organu rentowego wydana w sprawach o podleganie ubezpieczeniu społecznemu ma charakter deklaratoryjny, a nie konstytutywny ${ }^{35}$. Z istoty rzeczy takie rozstrzygnięcie zawiera w sobie stwierdzenie, że ziściły się ustawowe albo wynikające z ustawodawstwa unijnego (rozporządzenie podstawowe) przesłanki umożliwiające podleganie określonemu reżimowi ustawodawstwa, niezależnie od woli danej osoby, czy też powoływania się przez nią na czynności faktyczne (na przykład: rejestracja w systemie ubezpieczeń społecznych danego państwa członkowskiego, uzyskanie karty ubezpieczenia zdrowotnego). Również czynności faktyczne, prowadzone przez organ rentowy miejsca prowadzenia pozarolniczej działalności gospodarczej w trybie art. 16 rozporządzenia wykonawczego, nie mogą przesądzać o spełnieniu przesłanek zastosowania przepisów o koordynacji, w szczególności gdy zostały skutecznie zakwestionowane w odpowiednim trybie w jednym z państw członkowskich. Dodatkowo, uchylenie decyzji jednego organu rentowego państwa członkowskiego wzrusza podstawy porozumienia, a ono przecież stanowiło podstawę do objęcia osoby fizycznej obowiązkiem ubezpieczenia społecznego w kraju. Decyzja organu tego państwa jest bowiem decyzją zależną od

\footnotetext{
${ }^{34}$ Pojęcie sprawy unijnej zostało wypracowane w orzecznictwie Trybunału Sprawiedliwości Unii Europejskiej (zob. np. wyrok z dnia 22 maja 2008 r., C-499/06 w sprawie Halina Nerkowska przeciwko Zakładowi Ubezpieczeń Społecznych Oddział w Koszalinie, Dz. U. UE C.08.171.7/2). Uznano w nim, że sytuacje wchodzące w zakres stosowania ratione materiae prawa wspólnotowego obejmują w szczególności sytuacje wynikające z przyznanej przez art. 18 WE swobody przemieszczania się i pobytu na terytorium państw członkowskich (wyroki z dnia 15 marca 2005 r. w sprawie C-209/03 Bidar, Zb. Orz. s. I-2119, pkt 33, a także z dnia 12 lipca 2005 r. w sprawie C-403/03 Schempp, Zb. Orz. s. I-6421, pkt 17 i 18).

${ }^{35}$ Prawo do świadczeń z ubezpieczenia społecznego nabywa się z mocy prawa (ex lege), w razie zajścia sytuacji objętej ochroną (ryzyko ubezpieczeniowe) i po spełnieniu przez ubezpieczonego warunków nabycia danego prawa. Decyzja organu rentowego w kwestii prawa do świadczeń ma więc charakter deklaratoryjny, tj. stwierdzający zajście chronionej sytuacji i spełnienie (lub niespełnienie) wszystkich warunków nabycia prawa do świadczeń. Konstytutywny charakter ma jedynie decyzja Prezesa ZUS o przyznaniu prawa do renty w trybie art. 83 ustawy z dnia 17 grudnia 1998 r. o emeryturach i rentach z Funduszu Ubezpieczeń Społecznych (tak trafnie JęDRASIK-JaNkowska, Pojęcia, s. 146). W wyroku Sądu Najwyższego z dnia 10 czerwca 2014 r., sygn. akt II UK 464/13, OSNAPiUS 2015, nr 10, poz. 141, stwierdzono, że zasady podlegania określonemu rodzajowi ubezpieczeń społecznych wynikają z przepisów o charakterze bezwzględnie obowiązującym, kreujących stosunek prawny ubezpieczenia społecznego z mocy samego prawa i według stanu prawnego z chwili powstania obowiązku ubezpieczenia (wyrok Sądu Najwyższego z dnia 11 lutego 1999 r., sygn. akt II UKN 461/98, OSNAPiUS 2000, nr 7, poz. 286). Obowiązek ubezpieczenia oznacza, że osoba, której cechy, jako podmiotu ubezpieczenia społecznego, zostały określone przez ustawę, zostaje objęta ubezpieczeniem i staje się stroną stosunku ubezpieczenia społecznego niezależnie od swej woli, na mocy ustawy.
} 
porozumienia z organem rentowym innego państwa członkowskiego, a gdy decyzja składająca się na to porozumienie zostaje uchylona w postępowaniu sądowym, to odpada podstawa do wydania decyzji rozstrzygającej o podleganiu ubezpieczeniu społecznemu. Także i na te kwestie prawidłowo zwrócił uwagę Sąd Najwyższy w uzasadnieniu postanowienia z dnia 10 lipca 2018r., sygn. akt III UZ 10/18.

\section{WNIOSKI}

W okolicznościach sprawy przedstawionej na wstępie, Sąd Apelacyjny zasadnie nie podzielił poglądu, że procedura ustalania właściwego ustawodawstwa została prawidłowo przeprowadzona, skoro status ubezpieczenia D.Ś. na Słowacji nie został prawomocnie wyjaśniony. Z tej racji decyzja ZUS z dnia 14 lipca $2015 \mathrm{r}$. o podleganiu ustawodawstwu polskiemu, jak i wyrok sądu pierwszej instancji były przedwczesne. Okoliczności dotyczące zatrudnienia wnioskodawcy na terenie Słowacji, na podstawie umowy o pracę zawartej z A.B. - P.P.S., powinny zostać najpierw wyjaśnione przez słowacką instytucję ubezpieczeniową, a w razie uruchomienia postępowania odwoławczego, należało oczekiwać na jego zakończenie, gdyż zbieg tytułu do ubezpieczenia przyznaje pierwszeństwo umowie o pracę. Oczywiście, w wyniku tych ustaleń strony słowackiej mogłoby się np. okazać, że praca najemna świadczona na Słowacji miała charakter marginalny, bądź nie była w rzeczywistości wykonywana. Wtedy istniałyby podstawy do objęcia D.Ś. (kontynuacji) ubezpieczeniem społecznym z racji prowadzonej w Polsce pozarolniczej działalności gospodarczej. Sąd okręgowy na datę orzekania nie dysponował jednak materiałem dowodowym, pozwalającym na stwierdzenie o braku tytułu ubezpieczenia społecznego na Słowacji. Zatem nie był uprawniony do wydania merytorycznego orzeczenia kończącego. Powyższej oceny prawnej nie zmienia możliwość ponownego ustalenia podlegania (niepodlegania) ubezpieczeniu społecznemu (wznowienia postępowania) przewidziana w art. 83a ustawy o systemie ubezpieczeń społecznych. 


\section{BIBLIOGRAFIA}

\section{ŹRÓDŁA PRAWA}

Decyzja Komisji Administracyjnej ds. Koordynacji Systemów Zabezpieczenia Społecznego nr A1 z dnia 12 czerwca 2009 r. w sprawie ustanowienia procedury dialogu i koncyliacji w zakresie ważności dokumentów, określenia ustawodawstwa właściwego oraz udzielania świadczeń na mocy rozporządzenia Parlamentu Europejskiego i Rady (WE) nr 883/2004, Dz. U. UE C.2010.106.1.

Rozporządzenie Parlamentu Europejskiego i Rady (WE) nr 883/2004 z dnia 29 kwietnia 2004 r. w sprawie koordynacji systemów zabezpieczenia społecznego, Dz. Urz. UE L 2004.166.1.

Rozporządzenie Parlamentu Europejskiego i Rady nr 987/2009 z dnia 16 września 2009 r. dotyczące wykonywania rozporządzenia (WE) nr 883/2004 w sprawie koordynacji systemów zabezpieczenia społecznego, Dz. Urz. UE L 284.1.

Rozporządzenie Parlamentu Europejskiego i Rady (UE) nr 1215/2012 z dnia 12 grudnia 2012 r. w sprawie jurysdykcji i uznawania orzeczeń sądowych oraz ich wykonywania w sprawach cywilnych i handlowych, Dz. Urz. UE L 351 z późn. zm.

Ustawa z dnia 13 października 1998 r. o systemie ubezpieczeń społecznych, Dz. U. z 2017 r., poz. $1778 \mathrm{z}$ późn. zm.

Ustawa z dnia 17 grudnia 1998 r. o emeryturach i rentach z Funduszu Ubezpieczeń Społecznych, Dz. U z 2018 r., poz. 1270 z późn. zm.

\section{ORZECZNICTWO}

Postanowienie Sądu Najwyższego z dnia 1 czerwca 2011 r., sygn. akt II CSK 427/10, Legalis.

Postanowienie Sądu Najwyższego z dnia 14 listopada 2017 r., sygn. akt II UK 692/16, niepubl.

Postanowienie Sądu Najwyższego z dnia 10 kwietnia 2018 r., sygn. akt II UK 271/17, LEX nr 2510216.

Postanowienie Sądu Najwyższego z dnia 18 lipca 2018 r., sygn. akt III UZ 10/18, niepubl.

Wyrok Sądu Najwyższego z dnia 11 lutego 1999 r., sygn. akt II UKN 461/98, OSNAPiUS 2000, nr 7, poz. 286.

Wyrok Sądu Najwyższego z dnia 23 sierpnia 2007 r., sygn. akt I UK 68/07, OSNAPiUS 2008, nr 19-20, poz. 300 .

Wyrok Sądu Najwyższego z dnia 13 września 2010 r., sygn. akt II UK 82/10, OSNAPiUS 2012, nr 1-2, poz. 21.

Wyrok Sądu Najwyższego z dnia 6 czerwca 2013 r., sygn. akt II UK 333/12, OSNAPiUS 2014, nr 3, poz. 47.

Wyrok Sądu Najwyższego z dnia 10 czerwca 2014 r., sygn. akt II UK 464/13, OSNAPiUS 2015, nr 10, poz. 141.

Wyrok Sądu Najwyższego z dnia 21 stycznia 2016 r., sygn. akt III UK 61/15, LEX nr 1977828.

Wyrok Sądu Najwyższego z dnia 25 listopada 2016 r., sygn. akt I UK 370/15, LEX nr 2166375.

Wyrok Sądu Najwyższego z dnia 10 maja 2017 r., sygn. akt I UK 456/16, LEX nr 2352167.

Wyrok Europejskiego Trybunału Sprawiedliwości z dnia 15 grudnia 1976 r., C-39/76, L.J. Mouthaan, OCR 1976, s. 1901.

Wyrok Trybunału Sprawiedliwości Unii Europejskiej z dnia 10 czerwca 1986 r., 60/85, M. E. S. Luijten, ECR 1986, s. 2365.

Wyrok Trybunału Sprawiedliwości Unii Europejskiej z dnia 3 maja 1990 r., C-2/89, K. von Heijningen.

Wyrok Trybunału Sprawiedliwości Unii Europejskiej z dnia 20 września 1994 r., C-12/93, A. Drake., ECR 1994, s. 4337. 
Wyrok Trybunału Sprawiedliwości Unii Europejskiej z dnia 16 lutego 1995 r., C-425/93, Calle Grenzshop Andresen GmbH \& Co. KG, ECR 1995, s. 269.

Wyrok Trybunału Sprawiedliwości Unii Europejskiej z dnia 29 kwietnia 2004 r. w sprawie C-224/02 Pusa, Rec. s. I-5763.

Wyrok Trybunału Sprawiedliwości Unii Europejskiej z dnia 14 października 2004 r. w sprawie C-39/02, Marsk Olie \& Gas A/S v. Firma M. de Haan en W. de Boer.

Wyrok Trybunału Sprawiedliwości Unii Europejskiej z dnia 15 marca 2005 r. w sprawie C-209/03

Bidar, Zb. Orz. s. I-2119.

Wyrok Trybunału Sprawiedliwości Unii Europejskiej z dnia 26 maja 2005 r., C-249/04, J. Allard.

Wyrok Trybunału Sprawiedliwości Unii Europejskiej z dnia 12 lipca 2005 r. w sprawie C-403/03

Schempp, Zb. Orz. s. I-6421.

Wyrok Trybunału Sprawiedliwości Unii Europejskiej z dnia 18 lipca 2006 r. w sprawie C-406/04

De Cuyper, Zb. Orz. s. I-6947.

Wyrok Trybunału Sprawiedliwości Unii Europejskiej z dnia 26 października 2006 r. w sprawie C-192/05 Tas-Hagen i Tas, Zb. Orz. s. I-10451.

Wyrok Trybunału Sprawiedliwości Unii Europejskiej z dnia 22 maja 2008 r., C-499/06 w sprawie

Halina Nerkowska przeciwko Zakładowi Ubezpieczeń Społecznych Oddział w Koszalinie, Dz. U. UE C.08.171.7/2.

Wyrok Trybunału Sprawiedliwości Unii Europejskiej z dnia 10 marca 2011 r., C-516/09, T. Borger, C 139/8 Dz .Urz .UE 2011/C 139, poz. 11.

\section{LITERATURA}

ERECIŃSKI Tadeusz: Komentarz do art. 1098 k.p.c., [w:] Kodeks postępowania cywilnego. Komentarz. Tom VI. Międzynarodowe postępowanie cywilne. Sąd polubowny (arbitrażowy), red. T. Ereciński, Warszawa: Wolters Kluwer 2017, Lex/el.

JĘDRASIK-JANKOWSKA Inetta: Pojęcia i konstrukcje prawne ubezpieczenia społecznego, Warszawa: LexisNexis 2012.

MiąsıK Dawid: Zasada pierwszeństwa prawa wspólnotowego przed prawem krajowym- wprowadzenie i wyrok Trybunału Sprawiedliwości Wspólnot Europejskich z 29.04.1999 r. w sprawie C-224/97 Erich Ciola przeciwko Land Voralberg, Europejski Przegląd Sąowy 1 (2006), s. 54-56.

Mucha Joanna: Zawisłość sprawy w procesie cywilnym, Warszawa: Wolters Kluwer 2014.

ŚLEBZAK Krzysztof: Podleganie ubezpieczeniu społecznemu w przypadku jednoczesnego wykonywania pracy i prowadzenia działalności gospodarczej na terytorium przynajmniej dwóch państw członkowskich UE, Praca i Zabezpieczenie Społeczne 11 (2013), s. 30-35.

ŚLEBZAK Krzysztof: Ustalenie ustawodawstwa tymczasowego na podstawie rozporządzeń 883/2004 oraz 987/2009, Praca i Zabezpieczenie Społeczne 7 (2014), s. 2-7.

Torbus Andrzej: Komentarz do art. 1098, [w:] Kodeks postępowania cywilnego. Tom IV. Komentarz. Art. 1096-1217, red. A. Marciniak, Warszawa: C.H. Beck 2017, Legalis/el. 


\section{PROCEDURA USTALANIA WŁAŚCIWEGO USTAWODAWSTWA}

W SPRAWIE O PODLEGANIE UBEZPIECZENIU SPOŁECZNEMU

\section{Streszczenie}

W artykule poruszona zostanie ogólnie problematyka procedury ustalania właściwego ustawodawstwa, w przypadku zbiegu tytułów do ubezpieczenia społecznego w ramach porządków prawnych dwóch państw członkowskich, uregulowanej w art. 16 rozporządzenia Parlamentu Europejskiego i Rady nr 987/2009 z dnia 16 września 2009 r. dotyczącego wykonywania rozporządzenia (WE) nr 883/2004 w sprawie koordynacji systemów zabezpieczenia społecznego. Bezpośrednim powodem jego napisania było pytanie prawne zwykłego składu Sądu Najwyższego skierowane do składu powiększonego (vide: postanowienie z dnia 18 lipca 2018r., III UZ 10/18).

Słowa kluczowe: ubezpieczenie społeczne; procedura koncyliacyjna; organ rentowy; koordynacja systemów zabezpieczenia społecznego; zbieg tytułów do ubezpieczenia społecznego w ramach porządków prawnych dwóch państw członkowskich

\section{PROCEDURE FOR DETERMINING THE LEGISLATION APPLICABLE IN THE COURT MATTER FOR BEING SUBJECT TO SOCIAL SECURITY}

\section{Sum mary}

This article generally addresses the issue of procedure for determining the legislation applicable when entitlements to social security under legal orders of two member states coincide, regulated in art.16 of the Regulation (EC) No 987/2009 of the European Parliament and of the Council of 16 September 2009 regarding implementing Regulation (EC) No 883/2004 on the coordination of social security systems. The immediate reason for writing it was a legal question of the ordinary composition of the Supreme Court directed to its enlarged composition (Decision of 18 July 2018, III UZ 10/18).

Key words: social security; conciliation procedure; invalidity pension body; coordination of social security systems; coinciding of entitlements to social security under legal orders of two member states 